\title{
Spatial-Temporal Variability and Characterisation of Aerosols in Urban Air Quality of Ahmedabad, India, based on Field and Satellite Data
}

\author{
Rajesh Iyer ${ }^{1 *}$, Abha Chhabra ${ }^{2}$, Prakash Chauhan ${ }^{2}$, Tejas Turakhia ${ }^{1}$, Mohit Porwal ${ }^{1}$ and Divya Patel $^{1}$ \\ ${ }^{1}$ Department of Physics and Electronics, St. Xavier's College, Ahmedabad, Gujarat - India. \\ ${ }^{2}$ Space Applications Centre, ISRO, Ahmedabad, Gujarat - India. \\ Email: rajesh.iyer@sxca.edu.in
}

\begin{abstract}
Particulate matter (PM), or aerosol play an important role in Air Quality. Ahmedabad is an urban, industrialized and one of the fastest growing city in Western India. This study presents spatio-temporal variability in mass concentrations of different Particulate Matter as well as their characteristics during different seasons based on field measurements in different micro urban environments of Ahmedabad. The meteorological parameters such as wind speed, temperature, relative humidity and atmospheric pressure played a very important role in the seasonal variation of the PM concentrations. The $\mathrm{PM}_{10}, \mathrm{PM}_{2.5}$ and $\mathrm{PM}_{1}$ were found to be highest with $229.4 \mathrm{\mu g} / \mathrm{m}^{3}, 82.20$ $\mu \mathrm{g} / \mathrm{m}^{3}$ and $53.53 \mu \mathrm{g} / \mathrm{m}^{3}$, respectively in winter season. These PM concentrations are higher than the National Ambient Air Quality Standard (NAAQS) for $\mathrm{PM}_{10}$ and $\mathrm{PM}_{2.5}$. The aerosol characteristic based on field measurement of spectral Aerosol Optical Depth indicates significant contribution by coarser mode particles. The Inhalable, Thoracic and Alveolic PM concentrations which are significant for human health impacts of ambient air quality were observed in the increasing order of monsoon $<$ summer $<$ winter seasons. It is interesting to note that rainfall play a scavenging effect only on the coarser particles with mean $\mathrm{PM}_{1}$ values lowest in summer season $\left(20.4 \mu \mathrm{g} / \mathrm{m}^{3}\right)$ as compared to $\mathrm{PM}_{2.5}$ and $\mathrm{PM}_{10}$ which are lowest during monsoon season. Vertical profile of aerosols from spaceborne Cloud-Aerosol Lidar and Infrared Pathfinder Satellite Observations (CALIPSO) indicated a predominance of polluted dust type aerosols over the study area at height of $3-4 \mathrm{~km}$ which is important constituent of inhalable air of resident population. The results of this study may serve as important inputs for policy makers for formulating action plans and improving air quality by adopting suitable air pollution control measures in fast urbanising environment
\end{abstract}

Keywords: Particulate matter, seasonal variation, aerosol characterization, aerosol optical depth, space borne lidar data.

\section{Introduction}

Atmospheric aerosols or 'Particulate Matter' (PM) are solid or liquid particles or both suspended in air with diameter ranging from few nanometers to 100 microns in diameter. Aerosols may originate from natural or anthropogenic sources including vehicular emissions, biomass burning, fossil fuels burning etc. Aerosol particle size and size distribution are important physical properties governing aerosol interaction with atmospheric radiation, cloud formation, transport and deposition, and health effects [1]. In spite of significant advances in air pollution control, a serious problem in many cities is control of particulate matter (PM) concentration levels in the urban environment. Many studies have been conducted to monitor the concentrations of particulate matter in the indoor and outdoor environment and also to study their various sources in the developing countries [2-12]. Currently, PM pollution is the most pressing issue in air quality regulation worldwide besides one of the biggest sources of uncertainty in current climate [7]. Furthermore, atmospheric particulates also affect cloud formation and cessation, which regulate heat transfer in the atmosphere, thereby contributing to climate change. The monitoring of PM and its fractions is considered important in order to characterize the physical and chemical properties of particles, identify major particle sources and quantify their contributions, assess the spatial and temporal variability, and investigate the impact of particles on climate and health. 
The climatic effect of aerosols depends strongly on their optical properties, namely the aerosol optical depth (AOD), the Angstrom parameter, and the aerosol size distribution functions. All these, emphasize the need for extensive measurements and analyses of aerosol optical properties [13]. The AOD, which is the integral of the atmospheric extinction coefficient from the surface to the top of the atmosphere, is an important parameter for visibility degradation (due to atmospheric pollution), solar radiation extinction, climate effects, and tropospheric corrections in remote sensing [14]. The derivation of $\alpha$ in different wavelength regions is a useful tool for distinguishing and characterizing the different aerosol types [15]. The $\alpha$ parameter is qualitative indicator of aerosol particle size or fine mode fraction and also provides information on aerosol size distribution. These values have been used to characterize biomass burning aerosols, urban aerosols, maritime aerosol component in islands and desert-dust aerosols [16-25].

Very few studies have been reported in literature which have presented spatio-temporal variability in Particulate matter concentration and satellite derived AOD in urban environment of Ahmedabad. A study reported $\mathrm{PM}_{2.5}$ and $\mathrm{PM}_{10}$ varies in the range of 59 to $18 \mu \mathrm{gg} / \mathrm{m}^{3}$ and 144 to $56 \mu \mathrm{\mu g} / \mathrm{m}^{3}$ and satellite derived mean monthly AOD varied from 1.11 to 0.23 over the Ahmedabad district for the study year 2013. The study also reported that estimated mean annual AOD is higher over Ahmedabad city as compared to Ahmedabad district due to higher concentration of PM from urban vehicular exhaust and industrial emissions [26]. Another study presented spatio-temporal variations in MODIS derived AOD for the recent period 2012-2014. Higher AOD values in the range of 0.5-0.9 indicated urban Ahmedabad as "Fairly Polluted Area" [27]. PM concentration and their relationship with meteorology over Ahmedabad during 2005-2008 were studied [28]. Source identification of aerosol over urban Ahmedabad for a period of 3 years (2000-2003) were studied, however PM variations were not presented in this study [29].

The present study was aimed at understanding the spatial-temporal variability in PM concentration and aerosol characterisation based on field measurement over different locations representing different micro environments in urban Ahmedabad. The effects of meteorological parameters on PM mass concentrations were also studied in detail. The insitu AOD measurement were collected to understand the aerosol characteristics. The vertical profile and type of aerosols were studied using space borne lidar satellite data.

\section{Study Area}

The study area of Ahmedabad is located in Gujarat state with central latitude $23.03^{\circ} \mathrm{N}$ and longitude $72.58^{\circ}$ E. Ahmedabad experiences three distinct seasons of hot and dry summers to more humid in monsoon and moderately cold winters. The relative humidity ranges from $24 \%-55 \%$ in summers and $47 \%$ to $67 \%$ in winters. Field measurements were collected at 30 locations, chosen differ varieties of locations prevailing in city, like Industrial, Rural, Urban and Suburban, Traffic area of Ahmedabad city during winter (9-11 February, 2016), summer (13-14 May, 20016) and monsoon season (25-26 August, 2016). Figure 1 shows the locations (blue mark) which are selected for monitoring.

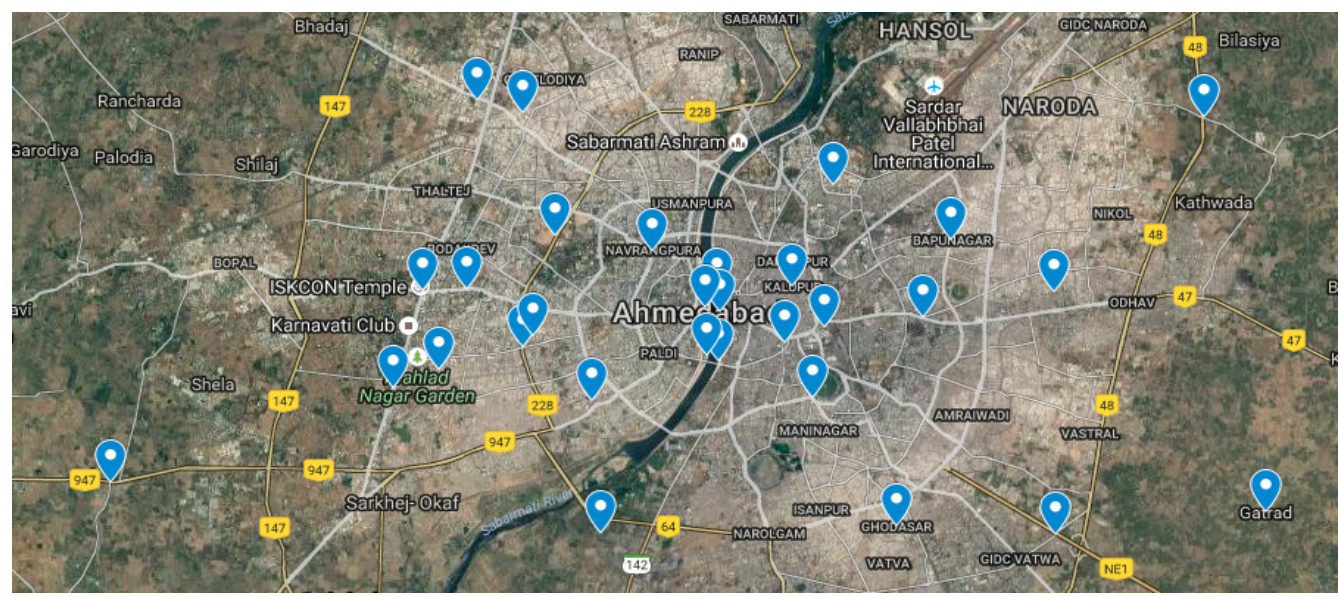

Figure 1. Ahmedabad Site with locations covered under this project 


\section{Instruments and Methods}

Different size PM were measured using Portable Grimm Spectrometer Model 11-A. This Spectrometer has wide particle size range $0.25 \mu \mathrm{m}-32 \mu \mathrm{m}$. This instrument also provides quantitative estimation of inhalable, thoracic and alveolic components of the total PM concentration. The instrument was kept at the height of about 7-8 feet above the ground that represents inhalable height for human. At each of the location the PM measurements were carried out every 10 minutes. The measurement sites were selected based on expanse and different microenvironments of Ahmedabad city.

AOD was measured at 28 different locations of Ahmedabad using a hand held Microtops-II Sunphotometer (Solar Light Co., USA) [30] at the recommended wavelengths of $340 \mathrm{~nm}, 500 \mathrm{~nm}, 870$ $\mathrm{nm}, 675 \mathrm{~nm}$ and $1020 \mathrm{~nm}$ respectively by the World Meteorological Organization respectively. All the measurements employing the sunphotometer and processing the data were carried out in accordance to a standard protocol. The vertical profile and type of aerosols were studied using NASA's space borne LIDAR CALIOP (Cloud-Aerosol Lidar with Orthogonal Polarization) sensor on-board CALIPSO (Cloud Aerosol Lidar and Infrared Pathfinder Satellite Observation) satellite [31].

\section{Results and Discussion}

\subsection{Spatial and Seasonal Variability in Particulate Matter (PM10, PM2.5 \& PM1) Concentration in Ahmedabad}

The detailed analysis of field data indicates large seasonal and spatial variability in PM concentration at different locations in Ahmedabad city. The $\mathrm{PM}_{10}$ and $\mathrm{PM}_{2.5}$ concentrations were observed to be highest during winter followed by summer and monsoon seasons. Mean $\mathrm{PM}_{10}$ and $\mathrm{PM}_{2.5}$ varies from $234 \mu \mathrm{g} / \mathrm{m}^{3}$ in winter to $50 \mu \mathrm{g} / \mathrm{m}^{3}$ in monsoon and $82 \mu \mathrm{g} / \mathrm{m}^{3}$ in winter to $35 \mu \mathrm{g} / \mathrm{m}^{3}$ during monsoon period respectively. However, mean $\mathrm{PM}_{1}$ values are observed to be highest in winter $\left(54 \mu \mathrm{g} / \mathrm{m}^{3}\right)$ and lowest in summer season $\left(20 \mu \mathrm{g} / \mathrm{m}^{3}\right)$. The seasonal variations in measured PM concentrations at different locations in Ahmedabad are shown in Figure 2. Also the metrological conditions during the study period are given in the table 1.

In winter the average spatial concentrations of $\mathrm{PM}_{10}, \mathrm{PM}_{2.5}$ and $\mathrm{PM}_{1}$ were found to be higher in the month of February. The inhalable, thoracic and alveolic values were also higher (table 1) for this season. Local pollution emissions are responsible for the higher concentrations due to increased human activity and more bonfires to combat cold. Moreover, low wind speed and high humidity 55-78\% during this season leads to reduced rate of removal of aerosol particles through scavenging [32].

Table 1. Metrological parameters over ahmedabad and average $\mathrm{PM}\left(\mathrm{PM}_{10}, \mathrm{PM}_{2.5}\right.$ and $\left.\mathrm{PM}_{1}\right)$, inhalable, thoracic and alveolic concentration during different seasons

\begin{tabular}{l|l|l|l}
\hline \multicolumn{1}{c|}{ Seasons } & Winter & Summer & Monsoon \\
\hline Pressure $(\mathbf{m b})$ & & & \\
\hline Humidity $(\mathbf{\%})$ & $1011-1020$ & $998-1013$ & $1003-1009$ \\
\hline Temperature $\left({ }^{\circ} \mathbf{C}\right)$ & 47 to 67 & 24 to 55 & $56-78$ \\
\hline Wind speed $(\mathbf{K t s})$ & 25 to 36 & 32 to 48 & 25 to 38 \\
\hline $\mathbf{P M}_{\mathbf{1 0}}\left(\mathbf{\mu g} / \mathbf{m}^{\mathbf{3}}\right)$ & $5-6$ & $6-8$ & $4-7$ \\
\hline $\mathbf{P M}_{2.5}\left(\mathbf{\mu g} / \mathbf{m}^{3}\right)$ & 234.8 & 154.2 & 50.1 \\
\hline $\mathbf{P M}_{\mathbf{1}}\left(\mathbf{\mu g} / \mathbf{m}^{3}\right)$ & 82.20 & 47.57 & 35.50 \\
\hline Inhalable $\left(\mathbf{\mu g} / \mathbf{m}^{3}\right)$ & 53.1 & 19.90 & 27.27 \\
\hline Thoracic $\left(\mathbf{\mu g} / \mathbf{m}^{3}\right)$ & 381.15 & 329.52 & 97.48 \\
\hline Alveolic $\left(\mathbf{\mu g} / \mathbf{m}^{\mathbf{3}}\right)$ & 234.83 & 162.89 & 53.06 \\
\hline
\end{tabular}



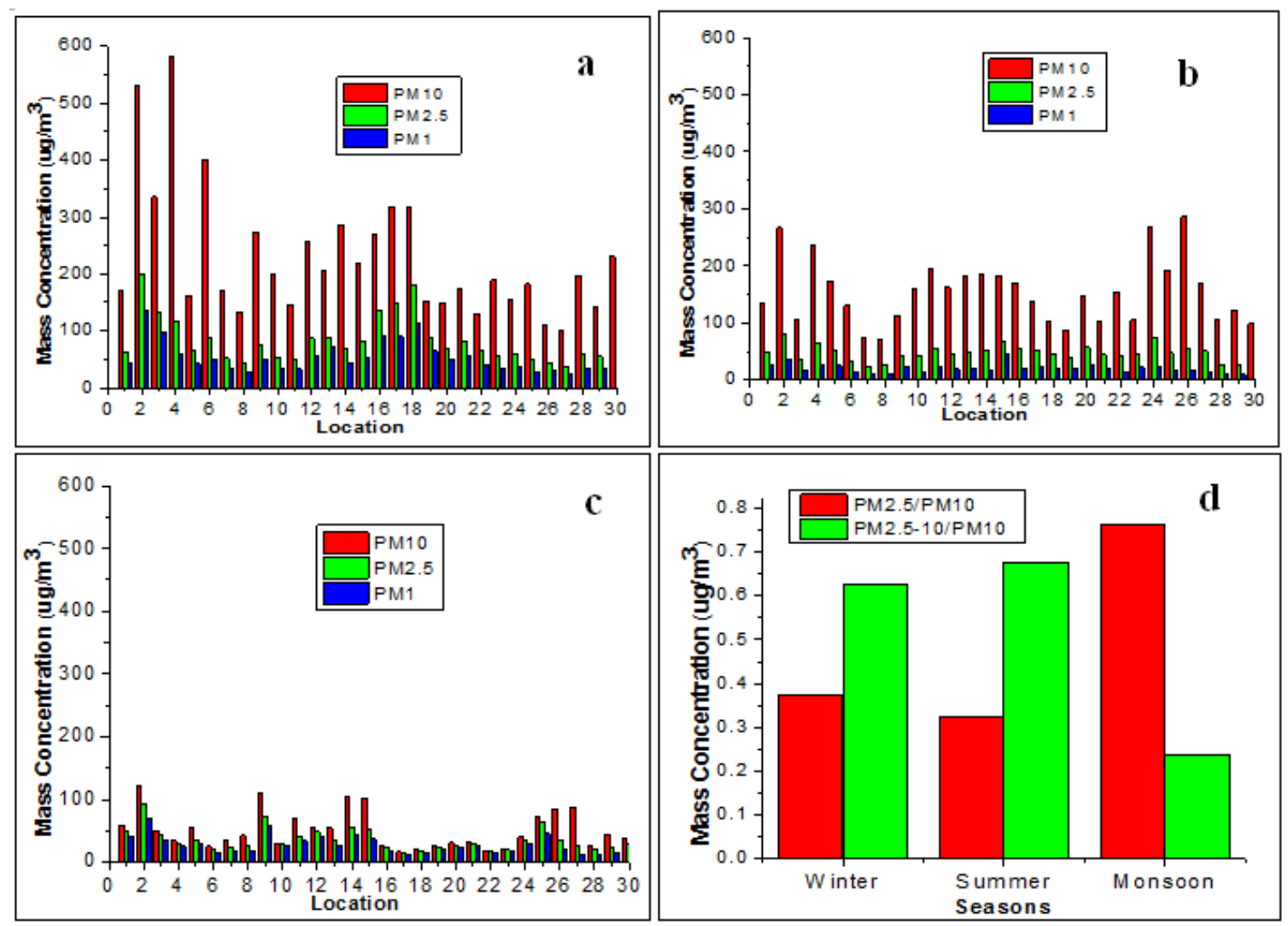

Figure 2. PM variation (a) during Winter (b) during Summer (c) during Monsoon (d) PM ratio for different season. [Locations: L1: Ghodasar, L2: Ramol GIDC Hathijan, L3: Gatrad, L4: Odhav GIDC, L5: Kankaria Lake, L6: Jamalpur Riverfront, L7: Ellis Bridge, L8: Nehru bridge, L9: Civil Hospital, L10: SP Ring Road, Vastral, L11: Rakhiyal, L12: Sarangpur, L13: Kalupur, L14: Bapunagar, L15: Gita Mandir ST, L16: Iscon Circle, L17: Neeldeep Clg Sola, L18: Sattadhar Circle, L19: SAC ISRO, L20: GMDC Ground, L21: Swastik Road, L22: Riverfront opp. Ashima, L23: Riverfront Paldi, L24: Pirana, L25: Vasna Bus Stand, L26: Shyamal Cross Road, L27: Prahlad Nagar, L28: Near Telav, L29: YMCA Club, L30: Nehrunagar]

In summer, during the month of May, the concentrations recorded were lower, as compared to those recorded during winter. This is possibly due to the increase in temperature and moderate wind speed. Particles are dry due to less humidity $35-48 \%$, and so contribute less in increasing their mass concentrations. Moreover during summer the prevailing winds caused by thermal circulations are stronger and the mixing height is deeper. Wind turbulence with greater mixing height results in proper dilution and dispersion of pollutants during summer $[33,34]$. The doors and windows are also kept open during the summer for proper air exchange rate which also reduces the concentration of PM especially of the fine particulate size indoors [35].

In Monsoon the concentrations are recorded lowest than in the winter and summer. This can be seen from figure 2 and table 1 . Lower aerosol concentrations were also observed in monsoon because of the washout effect of particles from the atmosphere. Larger super micron particles are removed faster than submicron particles and have little effect on their concentration [36]. Coarse particles, on absorbing water settles down and therefore resuspension and re-entrainment of soil is minimal and particulate matter during the monsoon is mainly composed of finer particles [37]. Interestingly the $\mathrm{PM}_{1}$ concentration was found to be lowest during summer instead of Monsoon. This clearly points to the fact that the scavenging factor does not affect finer particles. 
Table 2. PM(PM10, PM2.5 and PM1) and alveolic extremes concentration during different seasons. All the values are in $\mu \mathrm{g} / \mathrm{m}^{3}$

\begin{tabular}{l|l|l|l|l}
\hline Conc. & Extremes & Winter & Summer & Monsoon \\
\hline \multirow{2}{*}{ PM10 } & Max & 581.5 & 286.7 & 122.5 \\
\cline { 2 - 5 } & Min & 99.06 & 72.50 & 16.20 \\
\hline \multirow{2}{*}{ PM2.5 } & Max & 200.76 & 80.464 & 93.296 \\
\cline { 2 - 5 } & Min & 37.73 & 24.65 & 15.134 \\
\hline \multirow{2}{*}{ PM1 } & Max & 136.14 & 45.53 & 70.75 \\
\cline { 2 - 5 } & Min & 23.7 & 9.092 & 12.64 \\
\hline \multirow{2}{*}{ Alveolic } & Max & 272.46 & 119.15 & 103.58 \\
\cline { 2 - 5 } & Min & 52.09 & 34.053 & 15.535 \\
\hline
\end{tabular}

The PM concentration is higher than the NAAQS for $\mathrm{PM}_{10}\left(100 \mu \mathrm{g} / \mathrm{m}^{3}\right)$ and $\mathrm{PM}_{2.5}\left(60 \mu \mathrm{g} / \mathrm{m}^{3}\right) \mathrm{The}$ PM concentrations are higher in industrial areas $\left(582 \mu \mathrm{g} / \mathrm{m}^{3}\right.$ in winter to $123 \mathrm{\mu g} / \mathrm{m}^{3}$ in monsoon) and traffic junction $\left(320 \mathrm{\mu g} / \mathrm{m}^{3}\right.$ in winter to $72 \mathrm{\mu g} / \mathrm{m}^{3}$ in monsoon), while open areas like Public Park, colleges, etc., have low PM concentration $\left(99 \mu \mathrm{g} / \mathrm{m}^{3}\right.$ in winter to $16 \mathrm{\mu g} / \mathrm{m}^{3}$ in monsoon). During the Monsoon, there is a wet scavenging effect and the concentration steps down, but the scenario remains same for rest of the year. Ultimately, Alveolic particle concentrations were also seen high in industrial area $\left(272-103 \mu \mathrm{g} / \mathrm{m}^{3}\right)$, traffic areas and highways $\left(235 \mathrm{\mu g} / \mathrm{m}^{3}\right)$. This shows that these areas are more harmful for humans as we talk about health impacts, because alveolic (respirable) particles penetrate deep into the respiratory system. According to the survey of Ministry of Health and Family Department (MHFD) and Ahmedabad Municipal Corporation (AMC), 13856, 7168 and 9074 cases of Acute Respiratory Infection (ARI) and Influenza Like Illness (ILI) were recorded during winter, summer and monsoon seasons in Ahmedabad respectively. This is clearly a point of concern because overall average life expectancy is already low (64 years) in India; ranked 150 worldwide in 2012 and future increase in this concentration may worsen the situation [50].

\subsection{Ratios of Coarser and Finer PM in Ambient Air}

The $\mathrm{PM}_{10}, \mathrm{PM}_{2.5-10}\left(\mathrm{PM}_{10}-\mathrm{PM}_{2.5}\right), \mathrm{PM}_{2.5}$ and $\mathrm{PM}_{1}$ particles are relatively different in their physical and chemical compositions. The different size of atmospheric particles originates from different sources. The ratios of $\mathrm{PM}_{2.5} / \mathrm{PM}_{10}$ and $\mathrm{PM}_{2.5-10} / \mathrm{PM}_{10}$ have been used for identifying the sources of $\mathrm{PM}_{10}, \mathrm{PM}_{2.5-10}$ and $\mathrm{PM}_{2.5}$. Higher $\mathrm{PM}_{2.5} / \mathrm{PM}_{10}$ ratios indicate relatively high contribution from secondary particles and from the combustion sources, while lower ratios indicate significant contribution from primary sources such as resuspended soil/road dust and from other mechanical activities [38]. The annual and seasonal statistical summary of the ratios of $\mathrm{PM}_{2.5} / \mathrm{PM}_{10}$ and $\mathrm{PM}_{2.5-10} / \mathrm{PM}_{10}$ is given in figure $2(\mathrm{~d})$. On average for the 1 year data, the ratio of $\mathrm{PM}_{2.5} / \mathrm{PM}_{10}$ for winter and summer was found to be 0.37 and 0.32 respectively, which indicated that $\sim 35 \%$ of $\mathrm{PM}_{10}$ was made up of $\mathrm{PM}_{2.5}$ particles. The ratio of $\mathrm{PM}_{2.5-10} / \mathrm{PM}_{10}$ during winter and summer was found to be 0.63 and 0.67 during the study period, which is higher than $\mathrm{PM}_{2.5} / \mathrm{PM}_{10}$.

The results of the present study denote higher contribution of coarser particles to the $\mathrm{PM}_{10}$ concentration. Clinical and toxicological studies have reported that the coarser particles resulting from road dust (mixed debris from brake wear, tire wear, road abrasion, and biological and geological matter) can be as toxic as fine particles on a mass basis. As the role of particle composition in producing toxicity is uncovered, it becomes increasingly important to investigate the compositional differences between $\mathrm{PM}_{2.5}$ and $\mathrm{PM}_{2.5-10}$ as well as identify their sources. This is of particular importance in urban settings, where traffic-related PM is higher and coarse particles are largely made up of re-suspended road dust [39]. Monsoon is considered to be a special case of wet scavenging.

\subsection{Characterization of Aerosols in Urban Environment of Ahmedabad}

The AOD wavelength dependence is suitably expressed by the Angstrom-exponent $(\boldsymbol{\alpha})[40,41,15]$. The Angstrom turbidity coefficient $(\beta)$ is related to the amount of aerosols present in the atmosphere whereas the Angstrom exponent $(\alpha)$ yields information on the predominant size of suspended particles 
and it is also an indicator of the relative fine mode strength. The second-order Angstrom exponent $\left(\alpha^{\prime}\right)$ further quantifies the deviation from linearity of the spectral AOD variation in logarithmic coordinates. The Angstrom wavelength exponent $(\alpha)$ can be calculated using the AODs $(\tau)$ at two different wavelengths by applying Equation 1:

$$
\begin{gathered}
\tau(\lambda)=\beta \lambda^{-\alpha} \\
\alpha=\frac{d \ln \tau}{d \ln \lambda}=-\frac{\ln \left(\frac{\tau_{1}}{\tau_{2}}\right)}{\ln \left(\frac{\lambda_{1}}{\lambda_{2}}\right)}
\end{gathered}
$$

Equation (2) shows that $\alpha$ is the negative of the slope of $\tau$ with respect to wavelength in logarithmic scale. We make use of the derivative of $\alpha$ with respect to the logarithm of wavelength in order to compute the curvature of the $\ln \tau$ versus $\ln \lambda$ curves. The second derivative is a measure of the rate of change of the slope with respect to wavelength and, therefore is a complement to the Angstrom exponent, which is the negative of the slope (first derivative) of $\ln \tau$ versus $\ln \lambda$. We can calculate the second derivative of $\tau$ as follows:

$$
\alpha^{\prime}\left(\lambda_{i}\right)=\frac{d \alpha}{d \ln \lambda}=-\left(\frac{2}{\ln \lambda_{i+1}-\ln \lambda_{i-1}}\right) *\left[\frac{\ln \tau_{i+1}-\ln \tau_{i}}{\ln \lambda_{i+1}-\ln \lambda_{i}}-\frac{\ln \tau_{1}-\ln \tau_{i-1}}{\ln \lambda_{i}-\ln \lambda_{i-1}}\right]
$$

The $\alpha$ ' values were derived using the observed AODs at $340 \mathrm{~nm}, 500 \mathrm{~nm}, 870 \mathrm{~nm}$ and $675 \mathrm{~nm}$ wavelengths. The aerosol size distribution is rarely unimodal in the atmosphere due to different sources of origin and the mixing processes. Once the aerosol size distribution is multimodal, the wavelength dependence of AOD does not follow Equation (1) accurately. Consequently, a deviation from the linear behavior of $\ln \tau$ versus $\ln \lambda$ is expected and has been reported by several studies. The curvature in the AOD spectra could be expressed as a second-order polynomial fit, written as

$$
\ln \lambda=\alpha_{2}(\operatorname{lm} \lambda)^{2}+\alpha_{1}(\ln \lambda)+\alpha_{0}
$$

If $\alpha_{2}<0$ and $\alpha^{\prime}>0$, then the curvature will be concave indicating aerosol size distributions dominated by the fine mode and if $\alpha_{2}>0$ and $\alpha^{\prime}<0$, then the curvature will be convex indicating size distributions with a significant contribution by the coarse mode. Our result and calculation indicates contribution by coarse mode. The polynomial fit to Equation (4) is more precise than the linear fit to logarithms of Equation (1), while for low turbidity conditions large deviations in the above fits usually occur [42].

Table 3. AOD and angstrom parameters values

\begin{tabular}{l|l|l|l}
\hline AOD 500 & 0.384 & $\alpha_{340-870}$ & 0.924 \\
\hline AOD675 & 0.291 & $\beta$ & 0.223 \\
\hline AOD870 & 0.242 & $\alpha^{\prime}$ & -0.573 \\
\hline AOD340 & 0.573 & $\alpha_{0}$ & 0.25 \\
\hline$\alpha_{340-500}$ & 1.041 & $\alpha_{1}$ & -4.10 \\
\hline$\alpha_{675-870}$ & 0.734 & $\alpha_{2}$ & 14.78 \\
\hline
\end{tabular}

The average value of $\alpha$ calculated in the range $340-870 \mathrm{~nm}$ is 0.92 with turbidity parameter $(\beta)$ of 0.22 and average $\alpha$ of -0.57 . A value of $\beta>0.2$ usually indicates heavy pollution while $\beta>0.4$ indicates extremely heavy pollution. Large positive values of $\alpha^{\prime}$ are attributed to fine-mode dominated aerosol size distribution whereas close to zero and negative values of $\alpha^{\prime}$ are characteristic of size distributions with a dominant coarse mode [42]. The results show that in winter, the value of $\alpha_{2}$ is positive, signifying domination by the coarse-mode aerosols; these aerosols are of dust origin in the majority of the cases.

Extensive analyses based on spectral aerosol measurements indicate that the $\alpha$ varies with wavelength, and that the spectral curvature of the least-squares fit contains useful information about the aerosol size distribution [43-48]. More specifically, researchers investigated the sensitivity of $\alpha$ to both monomodal and bimodal aerosol size distributions, and explored the information content in the curvature of alpha. 
Different values of the fine-mode fraction strongly modify the curvature changing its sign from negative to positive [49].

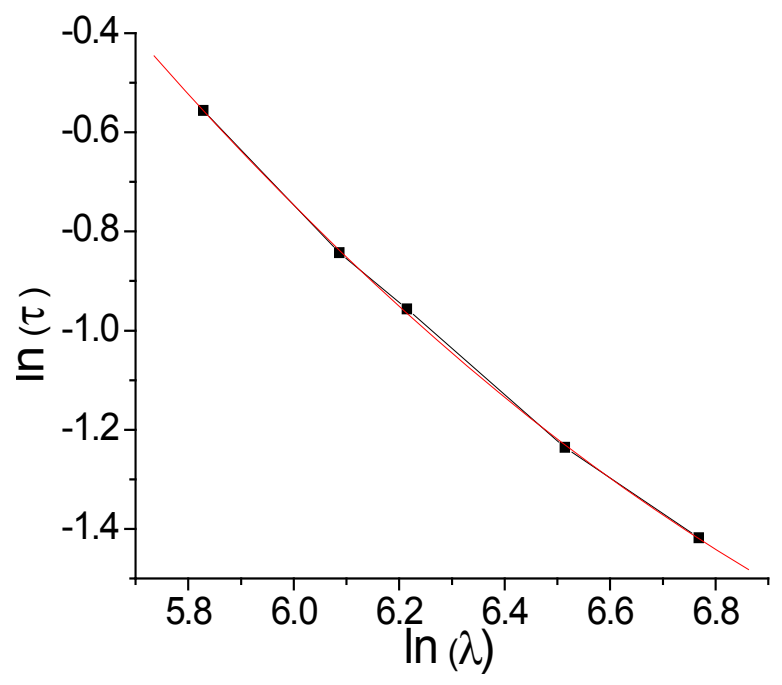

Figure 3. $\ln (\lambda)$ vs. $\ln (\tau)$ graph

Studies show that when $\alpha$ is close to unity, the coarse- and fine-mode aerosol concentrations are nearly equal and it gradually increases as the contribution of fine-mode aerosol concentration increases when one moves toward the more polluted areas. The $\alpha$ calculated using the spectral variation of AOD, has been used in various other previous studies as a tool to estimate particle size distribution and for extrapolating AOD throughout the broad spectral region as well as to distinguish the different aerosol types [42].

\subsection{Space Borne LIDAR Data Analysis over Study Site}

Space borne Lidar data of February, 2016 collected from CALIOP-CALIPSO [31] is given in Figure 4. The image clearly shows the dominance of dust and polluted dust type of aerosols over Ahmedabad and nearby regions at a height of about $3-4 \mathrm{kms}$ which also validates the results of aerosol coefficients indicating that Ahmedabad is dominated by coarse mode aerosols mainly contributed by polluted dust.

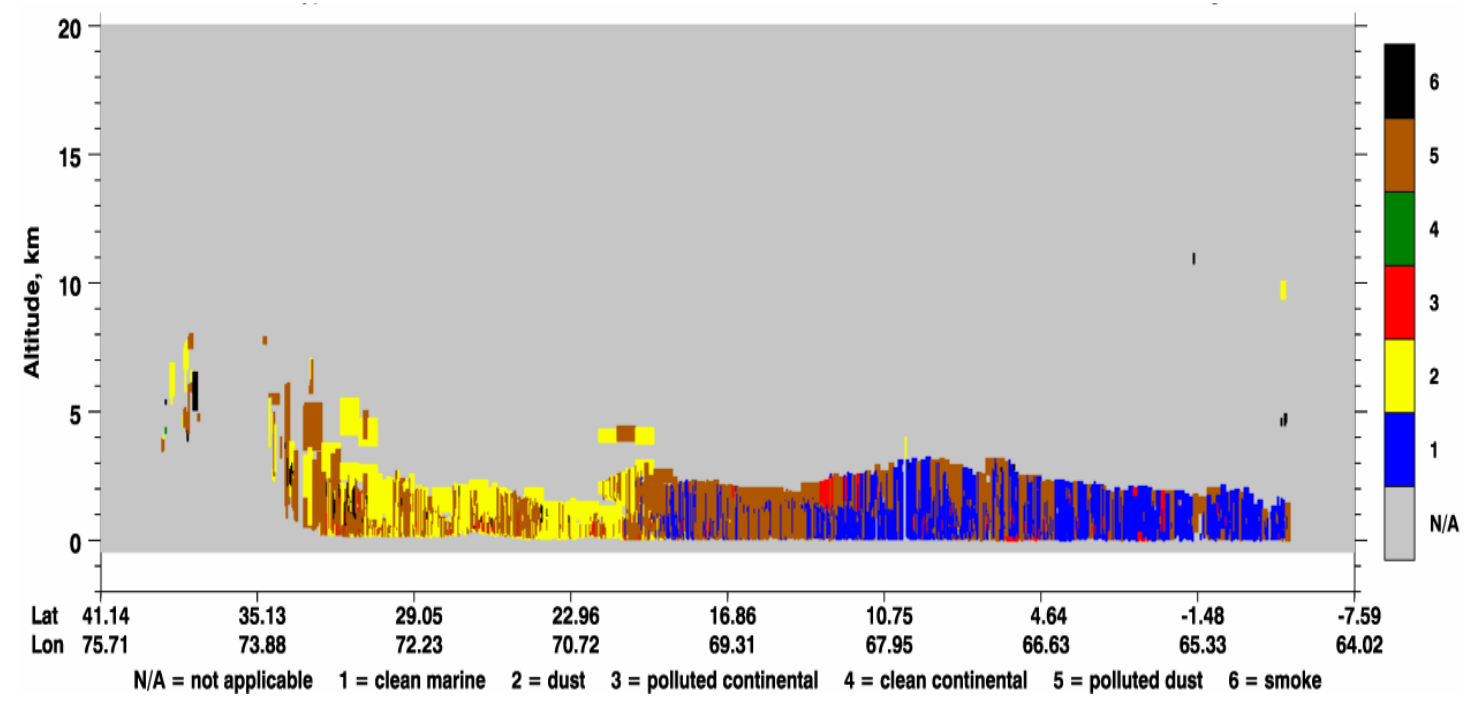

Figure 4. Vertical profile of aerosols studied using space borne lidar data 


\section{Conclusions}

Particulate Matter Aerosol constitute a significant component of urban air quality. This study presented spatio-temporal variation and characterization of PM aerosol in urban air quality over Ahmedabad, India. Results show that mean $\mathrm{PM}_{10}$ varies from $234.8 \mu \mathrm{g} / \mathrm{m}^{3}$ in winter to $50.1 \mathrm{\mu g} / \mathrm{m}^{3}$ in monsoon while $\mathrm{PM}_{2.5}$ varies from $82.2 \mu \mathrm{g} / \mathrm{m}^{3}$ to $35.5 \mu \mathrm{g} / \mathrm{m}^{3}$. However, mean $\mathrm{PM}_{1}$ values are observed to be the highest in winter $\left(53.1 \mathrm{\mu g} / \mathrm{m}^{3}\right)$ and interestingly lowest in summer season $\left(19.9 \mathrm{\mu g} / \mathrm{m}^{3}\right)$. The PM concentration is higher in industrial areas $\left(582 \mu \mathrm{g} / \mathrm{m}^{3}\right.$ in winter to $123 \mu \mathrm{g} / \mathrm{m}^{3}$ in monsoon) and traffic junction (320 $\mathrm{\mu g} / \mathrm{m}^{3}$ in winter to $72 \mathrm{\mu g} / \mathrm{m}^{3}$ in monsoon), while open areas like Public Park, colleges, etc., have low PM concentration $\left(99 \mathrm{\mu g} / \mathrm{m}^{3}\right.$ in winter to $51 \mathrm{\mu g} / \mathrm{m}^{3}$ in monsoon). Alveolic particle concentrations were also seen high in industrial area $\left(272-103 \mu \mathrm{g} / \mathrm{m}^{3}\right)$, traffic areas and highways $\left(235 \mathrm{\mu g} / \mathrm{m}^{3}\right)$. According to the data obtained from IDSP and AMC, ARI cases are almost twice during winter than the rest of the year. The $\mathrm{PM}_{2.5} / \mathrm{PM}_{10}$ and $\mathrm{PM}_{2.5-10} / \mathrm{PM}_{10}$ ratio indicates that the environment of Ahmedabad is dominated by coarser mode which contains mainly dust. The coarse mode domination is also verified through the CALIPSO satellite image over Ahmedabad. The AOD calculation further confirms the coarse mode domination and also points towards multimodal behavior of aerosols. Dominance of coarse-mode aerosols, particularly dust and polluted dust type aerosols in urban environment of Ahmedabad is evident from LIDAR and AOD measurements and measurement of PM concentration. This study provides useful insights to current state of sources, contribution and characterization of PM aerosol to urban air quality.

Acknowledgements. This study has been carried as a part of an ongoing research project titled: "Characterization of Aerosols, Black carbon and Radiative Forcing over Urban Environment of Ahmedabad and Gandhinagar city, Gujarat, India" under the RESPOND Programme of DOS/ISRO in association with Space Applications Centre, ISRO, Ahmedabad. We are thankful to DOS/ISRO for funding this research project and guidance received from concerned scientists of SAC, ISRO.

\section{References}

1. Piao, Casimiro A., Cardoso, J.G., Mário A. Cerqueira, Calvo, A., Teresa V. N., Alves, C.A., Custódio, D., Almeida, S.M. and Silva, M.A., "Seasonal variability of aerosol concentration and size distribution in Cape Verde using a continuous aerosol optical spectrometer." Frontiers in Environmental Science,2016.

2. Makkonen, U., Hellén, H., Anttila, P., Ferm, M., "Size distribution and chemical composition of airborne particles in south-eastern Finland during different seasons and wildfire episodes in 2006." Science of the Total Environment 408, $644-651,2010$.

3. Lim, J.M., Lee, J.H., Moon, J.H., Chung, Y.S., Kim, K.H., "Source apportionment of PM10 at a small industrial area using positive matrix factorization." Atmospheric Research 95, 88 - 100, 2010.

4. Dockery DW et al., "Effect of air pollution control on mortality and hospital admissions in Ireland.", Boston, Health Effects Institute (Research Report 176), 2013

5. Katsouyanni K, Touloumi G, Samoli E, Gryparis A, Le Tertre A, Monopolis Y, et al. "Confounding and effect modification in the short-term effects of ambient particles on total mortality: results from 29 European cities within the APHEA2 project. Epidemiology.", 2001; 12: 521-531.

6. N. Furuta, A. Iijima, A. Kambe, K. Sakai, K. Sato "Concentrations, enrichment and predominant sources of $\mathrm{Sb}$ and other trace elements in size classified airborne particulate matter collected in Tokyo from 1995 to 2004 " Journal of Environmental Monitoring, pp. 1155-1161, 2005

7. Fuzzi et al., "Particulate matter, air quality and climate: lessons learned and future needs." Atmos. Chem. Phys.15, 8217-8299, 2015.

8. Balakrishnan, K., Sambandam, S., Ramaswamy, P., Mehta, S., Smith, K.R. "Exposure assessment for respirable particulates associated with household fuel use in rural districts of Andhra Pradesh, India". Journal of Exposure Analysis and Environmental Epidemiology, 14, S14-S25, 2004.

9. Balakrishnan, K., Parikh, J., Sankar, S., Padmavathi, R., Srividya, K., Venugopal, V., Prasad, S., Pandey, V.L., "Daily average exposures to respirable particulate matter from combustion of biomass fuels in rural households of Southern India." Environmental Health Perspectives 110, 1069-1075, 2002. 
10.Dasgupta, S., Huq, M., Khaliquzzaman, M., Pandey, K., Wheeler, D., "Indoor air quality for poor families: New evidence from Bangladesh." Indoor Air 16, 426-444, 2006.

11.Saksena, S., Subida, R., Buttner, L., Ahmed, L., "Indoor air pollution in coastal houses of Southern Philippines." Indoor and Built Environment 16, 159-168, 2007.

12.Fullerton, D.G., Semple, S., Kalambo, F., Suseno, A., Malamba, R., Henderson, G., Ayres, J.G., Gordon, S.B., "Biomass fuel use and indoor air pollution in homes in Malawi." Occupational and Environmental Medicine 66, $777-783$.

13.Ogunjobi, K. O., He, Z., Kim, K. W., and Kim, Y. J.: "Aerosol optical depth during episodes of Asian dust storms and biomass burning at Kwangju, South Korea", Atmos. Environ., 38, 1313-1323, 2004.

14.Dubovik, O., Holben, B. N, Eck, T. F., Smirnov, A., Kaufman, Y. J., King, M. D., Tanr` e, D., and Slutsker, I.: "Variability of absorption and optical properties of key aerosol types observed in worldwide locations", J. Atmos. Sci., 59, 590-608, 2002.

15.Eck, T. F., Holben, B. N., Reid, J. S., Dubovic, O., Smirnov, A., O’Neil, N. T., Slutsker, I., and Kinne, S.: "Wavelength dependence of the optical depth of biomass burning, urban, and desert dust aerosols", J. Geophys. Res., 104(D24), 31 333-31 349, 1999.

16.Kaufman, Y. J., Gitelson, A., Karnieli, A., Ganor, E., Fraser, R. S., Nakajima, T., Matoo, S., and Holben, B. N.: "Size distribution and scattering phase function of aerosol particles retrieved from sky brightness measurements", Geophys. Res. Let., 99, 10 341-10 356, 1994.

17.Reid, J. S., Eck, T. F., Christopher, S. A., Hobbs, P. V., and Holben, B. N. "Use of the Angstrom exponent to estimate the variability of optical and physical properties of aging smoke particles in Brazil", J. Geophys. Res., 104(D22), 27 473-27 489, 1999.

18.Eck, T. F., Holben, B. N., Dubovic, O., Smirnov, A., Slutsker, I., Lobert, J. M., and Ramanathan, V.: "Columnintegrated aerosol optical properties over the Maldives during the northeast monsoon for 1998-2000", J. Geophys. Res., 106, 28 555-28 566, 2001a.

19.Eck, T. F., Holben, B. N., Ward, D. E., Dubovic, O., Reid, J. S., Smirnov, A., Mukelabai, M. M., Hsu, N. C., O' Neil, N. T., and Slutsker, I.: "Characterization of the optical properties of biomass burning aerosols in Zambia during the 1997 ZIBBEE field campaign", J. Geophys. Res., 106(D4), 3425-3448, 2001b.

20.Eck, T. F., Holben, B. N., Ward, D. E., et al.: "Variability of biomass burning aerosol optical characteristics in southern Africa during SAFARI 2000 dry season campaign and a comparison of single scattering albedo estimates from radiometric measurements", J. Geophys. Res., 108(D13), 8477, doi:10.1029/2002JD002321, 2003.

21.Keil, A. and Haywood, J. M.: "Solar radiative forcing by biomass burning aerosol particles during SAFARI 2000: A case study based on measured aerosol and cloud properties", J.Geophys. Res., 108(D13), 8467, doi:10.1029/2002JD002315, 2003.

22.Kaskaoutis, D. G. and Kambezidis, H. D.: "Investigation on the wavelength dependence of the aerosol optical depth in the Athens area", Q. J. R. Meteorol. Soc., 132, 2217-2234, 2006.

23.Smirnov, A., Holben, B. N., Kaufman, Y. J., Dubovic, O., Eck, T. F., Slutsker, I., Pietras, C., and Halthore, R. N.: "Optical properties of atmospheric aerosol in Maritime Environments", J Atmos. Sci., 59, 501-523, 2002.

24.Smirnov, A., Holben, B. N., Dubovic, O., Fruin, R., Eck, T. F., and Slutsker, I.: "Maritime component in aerosol optical models derived from aerosol robotic network data", J. Geophys. Res., 108(D1), 4033, doi:10.1029/2002JD002701, 2003.

25.Eck, T. F., Holben, B. N., Dubovic, O., Smirnov, A., Goloub, P., Chen, H. B., Chatenet, B., Gomes, L., Zhang, X. Y., Tsay, S. C., Ji, Q., Giles, D., and Slutsker, I.: "Columnar aerosol optical properties at AERONET sites in central eastern Asia and aerosol transport to the tropical mid-Pacific", J. Geophys. Res., 110, D06202, doi:10.1029/2004JD005274, 2005.

26.Rami, Y., Chhabra Abha, Pandya, M., "A study of spatio-temporal variations in Particulate Matter and Aerosol Optical Depth over Ahmedabad using field and satellite data". Proceedings of the National Conference on 'Transportation and Water Resource Engineering' (NCTWE-2015), pp. 356-361, 2015.

27.Rami, Y., Chhabra Abha, Pandya, M., "Remote sensing application to study ambient air quality over Ahmedabad. Multi-disciplinary Sustainable Engineering: Current and Future Trends" - Tekwani, Bhavsar \& Modi (Eds), Taylor \& Francis Group, London, ISBN 978-1-138-02845-6, 2016.

28.Bhaskar, B. Vijay, and Vikram M. Mehta. "Atmospheric particulate pollutants and their relationship with meteorology in Ahmedabad." Aerosol Air Qual. Res 10.4 : 301-315, 2010. 
29.Raman, Ramya Sunder, S. Ramachandran, and Neeraj Rastogi. "Source identification of ambient aerosols over an urban region in western India." Journal of Environmental Monitoring 12.6 : 1330-1340, 2010.

30.Solar Light Co. Inc., "Operational Manual of Microtops II Sun photometer," Solar Light Co. Inc.

31.LIDAR Image Database available at https://www-calipso.larc.nasa.gov

32.Kulshrestha A, Satsangi G, Masih J, Taneja A. "Concentrations of PM2.5 and PM10 particle and seasonal variations in urban and rural environment of Agra, India.", Sci Total Environ;407:6196-204, 2009.

33.Mantis J, Chaloulakou A, Samara S. "PM10-bound polycyclic aromatic hydrocarbons(PAHs) in the greater area of Athens, Greece.", Chemosphere ;59:593-604, 2005.

34.Kulshrestha A, Satsangi G, Masih J, Taneja A. "Metal Concentrations of PM2.5 and PM10 particle and seasonal variations in urban and rural environment of Agra, India.", Sci Total Environ; 407:6196-204., 2009.

35.Habil M, Taneja A. "Children's exposure to indoor particulate matter in naturally ventilated schools in India.", Indoor Built Environ.

36.Saha A, Moorthy KK. "Impact of precipitation on aerosol spectral optical depth and retrieved size distributions: a case study.", J Appl Meteor; 43:902-14, 2004.

37.Kumar AV. "Monitoring and modeling of ambient air quality at two traffic junctions in Mumbai." Ph.D. thesis submitted to Indian Institute of Technology, Bombay; 1998.

38.Dhananjay K. Deshmukh \& Manas K. Deb \& Stelyus L. Mkoma. "Size distribution and seasonal variation of size-segregated particulate matter in the ambient air of Raipur city, India", Air Qual Atmos Health, 6:259-276, 2013.

39.Shahir Masri, Choong-Min Kang, Petros Koutrakis. "Composition and Sources of Fine and Coarse Particles Collected during 2002-2010 in Boston, MA". J Air Waste Manag Assoc. 2015 Mar; 65(3): 287-297., 2015.

40.Holben, B. N., Tanre, D., Smirnov, A., Eck, T. F., Slutsker, I., et al.: "An emerging ground-based aerosol climatology: Aerosol optical depth from AERONET,” J. Geophys. Res., 106, 12 067-12 097, 2001.

41.Angstrom, A. K.: "On the atmospheric transmission of sun radiation and on the dust in the air", Geogr. ANN., 12, 130-159, 1929.

42.Kirti Soni, Sachchidanand Singh, Tarannum Bano, R. S. Tanwar \& Shambhu Nath, "Wavelength Dependence of the Aerosol Angstrom Exponent and Its Implications Over Delhi, India," Aerosol Science and Technology, 45:12, 1488-1498, 2011.

43.King, M. D. and Byrne, D. M.: "A method for inferring total ozone content from spectral variation of total optical depth obtained with a solar radiometer", J. Atmos. Sci., 33, 2242-2251, 1976.

44.O'Neill, N. and Royer, A.: "Extraction of bimodal aerosol size distribution radii from spectral and angular slope Angstrom coefficients", Appl. Opt., 32, 1642-1645, 1993.

45.O'Neill, N. T., Dubovic, O., and Eck, T. F.: "Modified Angstrom exponent for the characterization of submicrometer aerosols", Appl. Opt., 40(15), 2368-2375, 2001a.

46.O'Neill, N. T., Eck, T. F., Holben, B. N., Smirnov, A., and Dubovic, O.: "Bimodal size distribution influences on the variation of Angstrom derivates in spectral and optical depth space", J. Geophys. Res., 106(D9), 9787-9806, $2001 \mathrm{~b}$.

47.O'Neill, N. T., Eck, T. F., Smirnov, A., Holben, B. N., and Thulasiraman, S.: "Spectral discrimination of coarse and fine mode optical depth", J. Geophys. Res., 198(D17), 4559, 2003.

48.Kaskaoutis, D. G., Kambezidis, H. D., Adamopoulos, A. D., and Kassomenos, P. A.: "Comparison between experimental data and modeling estimates of atmospheric optical depth over Athens, Greece", J. Atmos. Solar Terr. Phys., 68, 1167-1178, 2006.

49.D. G. Kaskaoutis, H. D. Kambezidis, N. Hatzianastassiou, P. G. Kosmopoulos, and K. V. S. Badarinath "Aerosol climatology: dependence of the Angstrom exponent on wavelength over four AERONET sites"

50.Ghude, S. D., D. M. Chate, C. Jena, G. Beig, R. Kumar, M. C. Barth, G. G. Pfister, S. Fadnavis, and P. Pithani, "Premature mortality in India due to PM2.5 and ozone exposure", Geophys. Res. Lett., 43, 2016. 